\title{
ENGLISH LITERATURE TEACHING AN INDONESIAN CONTEXT
}

\author{
Nita Novianti \\ Universitas Pendidikan Indonesia \\ nitanoviantiwahyu@upi.edu
}

First received: 22 April $2016 \quad$ Final proof received: 18 July 2016

\begin{abstract}
Literature has gained an increasingly important place in language learning. Particularly in the EFL context, it has been regarded as beneficial for the improvement of English skills. However, there is not much attention given to the teaching of English literature for the sake of literature, not merely as a tool or technique in language learning, especially in Indonesia. The research therefore aims to investigate the teaching of English literature to EFL students in Indonesian universities. More specifically, it attempts to find how English literature lecturers select literary texts, what problems encountered by lecturers in teaching English literature to EFL students, and how they cope with the problems. A case study to three lecturers teaching three different literature courses in a state university in Indonesia was conducted. The findings show that: First, lengths, levels of language difficulty, canonical status, and the cultural background of the author become the main consideration for selecting the literary texts to teach; Second, the problems encountered are of threefold, namely reading habit, English proficiency, and resources; and Third, some of the strategies to cope with the problems consist of individual reading assignment, reading group, and taking the most advantage of the internet for teaching resources. This research has demonstrated that there are many areas for further studies in the teaching of English literature to EFL students in Indonesia, finding effective teaching models is one of them.
\end{abstract}

Keywords: English Literature, EFL, Indonesian context

The study of language has been increasingly inseparable from the study of literature. This is also the case with the study of English language and literature. In fact, literature serves a significant role in the teaching and learning of English, especially for non-native speakers of English, either ESL (English as a Second Language) or EFL (English as a Foreign Language) students. Literature is also deemed to be able to enrich the cultural knowledge of students, which is an integral part of language learning (Carter \& Long, 1991). Hence, many studies have been devoted to the teaching of English through literature to ESL/EFL students.

In general, research has shown that literature is very beneficial in helping students acquire the four language skills (reading, writing, listening, and speaking) and vocabulary, grammar, and pronunciation, either as excellent resources for English teaching and learning materials (Elklic, ErGgen, Kayintu, \& Karaca, 2011; Floris, 2004; Khatib, Rezaei, \& Derakhshan, 2011; Maley, 1989; McKay, 1982; Riverol, 1991; Turker, 1991; Yeasmin, Azad, \& Ferdoush, 2011); a popular technique (Hişmanoğlu, 2005); or an effective source for increasing students' creativity and imagination (Daskalovska \& Dimova, 2012), enhancing motivation (Sell, 2005; Vural, 2013), and promoting cultural awareness (Cruz, 2010). Some research has also focused on the particular approaches of teaching English through literature, such as using literary analysis (Van, 2009), task- based-approach (Khatib et al., 2011), integrated approach (Healy, 2010; Zyngier, 1994), and developing the three approaches put forward by Carter and Long (1991) (Bedi, 2011; Bibby and Mcllroy, 2013). More specific research on the use of literature to teaching English in ESL/EFL classes has been done, with some focusing on the use of poetry (Llach, 2007; Yavuz, 2010), children's literature (Chang, 2009; Sidhu, Fook, \& Kaur, 2010), and short stories (Saka, 2014). A large amount of the research has also been devoted to find teachers and students' perceptions of the use of literature in English learning in EFL secondary schools (Tasneen, 2010) and university (Abdullah, I., Zakaria, Ismail, Mansor, \& Aziz, 2007, Padurean, 2015). The rich body of research in the field of English teaching and learning through literature proves that literature serves an important part.

However, little attention has been given to the teaching of English literature to non-native speakers of English (ESL/EFL) for the sake of teaching literature with language learning as an integral part of it; in other words, English literature is not merely treated as a resource, technique, or method to improve English skills. Quite popular is research investigating approaches to teaching literature at the level of secondary school, such as a comparison of language-based approach and integrated approach (Aziz \& Nasharudin, 2008), a comparison of information-based and moral-philosophical approaches (Rashid, Vethamani, Rahman, 2010), a 
comparison of paraphrastic, information-based, and moral-philosophical approaches (Hwang \& Embi, 2007). Similar research on particular methods in teaching literature to non-native speakers of English has also been conducted, such as the use of a certain novel to introduce classic English literature (Bjarkadottir, 2009), the use of computer-assisted literature teaching (Tseng, 2010), the use of studentcentered teaching of poetry (Vasuthavan \& Kunaratnam, 2009), and the use of activity-based literature learning (Neranjani, 2011). Most of the research was carried out in countries where English is either the second official language (ESL), or the English curriculum requires the teaching of literature to be integrated into the teaching of English, particularly at the level of secondary school.

Meanwhile, research on the teaching of literature at the level of university is relatively scarce compared to that of secondary education. In the context of Finland, a teacher's reflection was carried out by Chesterman (1983), focusing on the possibility of implementing a particular model of teaching poems to Finnish EFL students; however, the model was not tested or implemented in real classroom setting. Research on the teaching of English literature to ESL students in the real classroom settings was conducted by Ghouti and Mohammed (2014) on the use of integrative approach to promote the learning of culture in ESL classrooms of English Department at the level of university. There are also some studies exploring techniques or methods to teach literature in college, among others, investigating the effect of the use of media, especially the internet, in teaching English literature (Khalid \& Muhammad, 2012; Li, 2011). Meanwhile, a literature review particularly describing the current situation and problems as well their solutions in the teaching of literature in the context of EFL in China was conducted by Zhen (2012) which was based on the researcher's own experience.

As can be seen from the literature of research on teaching English literature in the context of ESL/EFL above, the teaching of English literature to non-native speakers of English as separate from the teaching of language in the context of university is not as rigorous as that of research on the same topic at the level of secondary schools, and is far lagged behind from research on the teaching of English through literature. In Indonesia, more particularly, it is hard to find research in this area, notwithstanding the fact that English Literature department or program has flourished in a number of universities in Indonesia. Therefore, the present study will fill in the gap by investigating the teaching of English literature to non-native speakers of English at the level of university. More particularly, the aims of the study are formulated into the following research questions:
1. How do English literature lecturers select the texts for the teaching and learning?

2. What problems are encountered by lecturers in teaching English literature to EFL students?

3. How do the lecturers cope with the problems?

The findings of this research will help delineate the current trends in the teaching and learning of English literature in undergraduate classes of English literature study programs or departments in Indonesia. More importantly, the findings will be used to design a model of teaching English literature appropriate to the context of Indonesia. In addition, as part of the research roadmap, the model resulted from the present research will be tested and implemented in the subsequent research to find its effectiveness.

\section{Literature Review \\ The Teaching of English Literature in EFL \\ Context}

Compared to the long-standing and well-established English language study, English literary study can be said to be relatively new, particularly in EFL countries (Carter \& Long, 1991). With this history, literature is sometimes regarded as being less important than language, especially so in countries where English is a second or foreign language. Kateregga (2014), for instance, observed that many Ugandan students are reluctant to learn literature because they think that unlike language, learning literature does not help them get employment. Similar situation is reflected in Indonesia, where people commonly question the kinds of employment that are suitable for English literature graduates and whether they will ever get one. Therefore, it is not uncommon to find many English teachers treat literature only as a tool, a resource, or an aid in helping students learn English.

Another reason behind the reluctance to teach and study English literature is, according to Sell (2005), concerned with political and methodological matters. Politically speaking, quite a few teachers of English in EFL countries think that by teaching English literature they are maintaining the imperial culture, whose canons are dominated by white male authors. Methodologically, Sell reported that English teachers view literature as being "unrealistic", which is contradictory to the nature of English learning that should be practical and "realistic." In addition, "teaching literature entails an imbalance of power and work in the teacherstudent relationship, for the teacher is more knowledgeable and takes a more dominant role in communicating that knowledge" (p. 88). This method of teaching is very contradictory to the student-centered learning that is highly promoted in today's classes. Methodologically speaking, 
Padurean (2015) also observed that many teachers "consider that the language used in literary works is too complex and difficult and therefore it does not support students in the acquisition of grammar and lexical structures that can be used in their everyday lives" (p. 195).

With an increase in the awareness of the importance of reading, and hence literature, especially since the 1980 s there has been a revival of interest in teaching English Literature, both as an end of it self and as a means to reach an end, which is language proficiency (Carter \& Long, 1991; Hişmanoğlu, 2005; Vural, 2013; Zhen, 2012). More specifically, Zhen (2012) explained that the teaching of literature in EFL context is characterized by an emphasis on facilitating the improvement of English skills rather than literary appreciation and knowledge of culture. Carter and Long (1991) in particular emphasized the importance of learning literature for non-native speakers of English. The aims of teaching literature as stated by Burke and Brumfit (2000) (cited in Neranjani, 2011) are to simultaneously promote students' literary skills and social skills and to encourage liberal, ethical, and humanitarian attitudes as well as providing necessary information and knowledge regarding literary traditions and language. With the revival of English literature teaching and learning, approaches to teaching literature, particularly for the non-native speakers of English, were designed. To this date, the three approaches to teaching literature proposed by Carter \& Long (1991) have been popularly used, namely the language model, the cultural model, and the personal growth model. The three models will be briefly discussed below.

The Language Model. As the name suggests, this model of teaching literature focuses on how language is used in literary texts. It embarks from a belief that literary language is different from the ordinary, everyday use of language, hence worth studying. With the focus on grammar, syntactical, and lexical aspects of the literary texts, this approach "is considered too mechanistic and demotivates the pleasure of reading literature" (Padurean, 2015, p. 196). In other words, this approach does not regard literary texts as a work of art whose aesthetics can be appreciated, but merely a collection of information that can be decoded through the analysis of the linguistic features.

The Cultural Model. In this approach, literary texts are not treated as resources of information and linguistic features beneficial for the acquisition and/or learning of English. Often regarded as an expansion of the language model, this approach also treats literary texts as resources to learn about the culture and ideology of the respective author or the characters and settings of the texts (Carter \& Long, 1991). The drawback of this model is sometimes the lack of focus on the linguistic elements that make up the meanings of the text.
The Personal Growth Model. This model combines the language and cultural models, looking at linguistic elements in the context of the text's culture. Students are given freedom to express their aesthetic appreciation of the literary texts and interpret the cultural as well as ideological values contained in the texts while studying or analyzing the linguistic elements of the text.

These three approaches to teaching English literature have experienced development and adjustment as they are practiced in the respective context of the teaching and learning. Due to the limited research in the field of English literature teaching in Indonesia, not much is known regarding the development of these approaches or even the current situation of English literature teaching and learning in the classrooms. Therefore, it is necessary that research shedding light on the teaching of English literature be done. The next section will describe the method of this research.

\section{METHOD}

Due to the nature of the problems investigated and the aims of describing and explaining the teaching of literature in the EFL context in Indonesia, the present research adopted a case study approach. According to Yin (2009a: p. 18; 2014) as cited in Malik and Hamied (2016), case study research is an "empirical inquiry about a contemporary phenomenon or a case set within the real world context-especially when the boundaries between phenomenon and context are not clearly evident ( $\mathrm{p}$. 240)." The contemporary phenomenon here is the teaching and learning of English literature in the context of undergraduate classes in an Indonesian university. This phenomenon is a case worth studying not only because there has not been much research probing into this case, but also because English literature study in Indonesia is highly inseparable from English language studies. In fact, in the university under study, English literature study program is nested under the Department of English Education. Consequently, it is not uncommon that English literature lecturers have English education major as their background.

Data were collected through a year-long observation of the teaching and learning process in the undergraduate English literature classes in a state university in West Java, Indonesia. There were three literature classes observed, each with a different course and different student classification, namely: A freshman class of "Foundation of Literature", a sophomore class of "Exploring Fiction", and a junior class of "Literary Theories." To buttress the data for analysis, interviews were conducted to three English literature lecturers. In addition, the syllabi (documents) of the courses that these lecturers taught were collected and analyzed. The selection of the subjects in this research was 
based on the consideration of accessibility. The researcher is able to access all relevant data important to this research, as data accessibility is one of the prerequisites for conducting a case study (Malik \& Hamied, 2016). The subsequent section presents and discusses the findings of the study.

\section{FINDINGS AND DISCUSSION}

In general, it is found that English literature teaching in Indonesian context does not differ much from that in similar countries, where English is the foreign language. Nevertheless, there are some differences worth pointing out, as will be discussed further in the rest of the section.

\section{Text Selection for English Literature Teaching to EFL Students}

Literature teaching means dealing with texts of various genres, but ultimately the prose, poetry, and play or drama. Hence, English literature lecturers' first important and inarguably most difficult task is to select the "right" texts for their students. Based on the review of documents (lecturers' syllabi) and interview with the lecturers, it is found that learners' English skills become the main consideration for selecting literary texts. The lecturers avoid assigning students with lengthy literary texts, such as novels. They would choose novella instead of novels, for instance. Length, according to Than (2002), should indeed be the major consideration for selecting literary texts for the teaching of English literature in EFL context: "short literary texts are better than the lengthy ones for classroom use" (p. 43). Hence, the syllabi show that the majority of texts taught to students are dominated by short story, poem, novel, and play, respectively.

In addition to length, levels of language difficulty, such as vocabulary and grammatical structure, are taken into account when selecting the texts. Canonical works such as the plays and novels written by Shakespeare, Dickens, Woolf, Joyce, and other Western Canon authors, are often omitted, notwithstanding their importance due to the possible difficulty that students will encounter with the linguistic elements of the texts. This decision is considered apt because as put forward by Carter \& Long (1991), there is a potential danger of introducing canon literature to EFL learners. Learners who find the works difficult to comprehend, either because of difficult vocabulary or grammatical structures, will probably be demotivated to continue reading the texts. Chang (2003) added, "An efficient reading of canonical texts, besides L2 linguistic knowledge, requires an adequate knowledge of other kinds, world knowledge, foreign cultural literacy, literary knowledge, and knowledge of conventions" (pp. 3132). Thus, teaching canonical texts is really challenging and should be taken very seriously.
However, since literary canons are an inseparable part of English literature, the lecturers argued that the canonical texts should still be taught to students. To accommodate this, some of the lecturers choose to teach canonical texts that have been simplified or "modernized", whereas the other lecturer resorts to shorter canonical texts, such as short story and novella. When teaching the famous Macbeth by Shakespeare, for instance, a lecturer decides to assign her students to read the graphic novel of the play. Besides shorter than the original text, the graphic novel also has more appeal to students. As the lecturer reports, more students completed the reading task than they did for other reading assignments.

Another consideration taken by the lecturers in selecting literary texts is content and the culture from which the authors of the text come. The lecturers not only focus on the literary canons from the British and American Literature, but they also introduce literature from the marginalized culture and gender. According to Carpenter (2007, p. 4), "The voices of the marginalized and the oppressed are lacking in canonical literature for the English classroom, and our students need to hear these voices . . . Literature in the English classroom should give students the opportunity to explore the voices of a diverse range of people." Hence, one lecturer, for example, assigns the reading of a novel by a Native American female author to the students. This selection is to broaden students' knowledge and insight of how diverse and rich English literature is.

After finding about the ways the lecturers select literary texts for the teaching and learning, the subsequent part will discuss the problems that the lecturers face in teaching.

\section{The Problems Encountered by Lecturers in Teaching English Literature to EFL Students}

Classroom observations and interviews with the lecturers reveal some important problems to the teaching and learning of literature in Indonesian EFL undergraduate classes. The problems can be classified into several categories, namely: reading habit, English proficiency, and resources.

The lecturers all agree that to start with, students are not avid readers; they do not make reading as a habit. Many students are not really fond of reading, even the majority of them also have not read much Indonesian literature. As a result, it is not infrequent that some students come to the class unprepared, not reading the assigned text or chapter. This problem of reading habit has also been observed by Chesterman (1983) in the context of teaching English literature in Finland, where he noticed that "students appear not to have had much experience of reading literature even in their native language" (p. 135). In addition, there is a noticeable gap in the number of students who read literature on 
a regular basis and those who do not, with the former being outnumbered by the latter. A small number of students even admitted that they did not like reading any type of texts, but ultimately literary texts.

Language proficiency is also another important problem that lecturers need to tackle in teaching English literature to their EFL students. Language proficiency is, indeed, one of the major problems also observed by researchers (Chang, 2003; Chesterman, 1983; Than, 2012; Zhen, 2012) who are concerned with the teaching of English literature in EFL context. In the classes under research, it is commonly the case that students have different levels of language proficiency, with a huge gap between those with high level of language proficiency and those with the low level. This gap creates a conspicuous imbalance in the class, where those with higher level of English proficiency seem to dominate the classroom discussion, unless the lecturers encourage the other less proficient students to also join the discussion.

Resources become another problem that may seem rather trivial, but actually is really important. It is common that textbooks and other instructional materials written by scholars abroad are hard to obtain. While literary canons are available online and can be accessed freely, the same is not true for other literary texts and especially textbooks and articles on literary theories and literary criticism. This problem is also observed by Zhen (2012) in the context of English literature in EFL in China. Among the four major problems in the teaching of English literature in China that she observes, inadequate and inappropriate teaching and learning resources is one of them.

After successfully identifying the problems English literature lecturers encounter in the teaching and learning process, it is necessary to find how these lecturers cope with the problems in order to find the best practices of English literature teaching. These best practices will then be formulated into an instructional model.

\section{The Strategies to Cope with Problems in Teaching Literature to EFL Students}

For the specific context of Indonesian EFL literature classes, especially the classes under study, the strategies should be formulated to address the problems peculiar to the context. As has been previously explained, there are three major problems found in the teaching of Literature to Indonesian EFL students: reading habit, language proficiency, and resources. The strategies are then formulated on the basis of best practices observed in the class during research.

Reading habit. There are several methods employed by the lecturers to increase students' reading habit. A particular strategy that is quite successful as observed by the researcher is the individual reading assignment. In this particular assignment, students are assigned a particular chapter of a novel or a short story or a poem by the lecturer. Each student then individually has a discussion with the lecturer. The lecturer asks questions to students to assess students' understanding of the text. This task is particularly challenging to students because they have to show to the lecturer that not only have they read the text, they also have understood what the text is about. This way of checking students' reading individually also has considerably reduced the number of students who come to the class unprepared, without reading the assigned text(s).

Language Proficiency. Students' English proficiency differs at the level of age or year of study and also within the same level or class. The former means students who are freshmen tend to have lower level of English proficiency than those who are at the classifications of sophomore and junior. The latter means that even in the same year or class, students do not have the same English proficiency, and the gap is sometimes really wide. Thus, the lecturers first of all select the text carefully based on these differences. For the freshmen, they assign the reading of short story and poems. In addition to being relatively shorter, the texts assigned to students at the lower level tend to contain rather simple vocabulary and grammatical structures. Meanwhile, for the upper levels, the texts assigned are relatively longer with rather complex vocabulary and grammatical structure.

To address the gap in the language proficiency of students within the same class, the lecturers implement two techniques. The first is reading group, which is carefully selected on the basis of students' levels of English proficiency. Within the same group, the lecturers assign students with different proficiency levels. The students are asked to share their understanding of the text. This way, those with the low proficiency can be helped by those with higher level of proficiency. Some of the lecturers also assign students to always list the difficult vocabulary encountered during reading and discuss the words based on the contexts in the texts.

Resources. This problem is particularly difficult to solve because it requires the cooperation from the department and the university. English literature textbooks and research articles on literary criticism/theory are difficult to obtain and expensive. The department needs to allocate a certain budget to help with the provision of the necessary textbooks. In the meantime, internet seems to be really helpful in providing the resources for the teaching. Most of the canonical texts are accessible and downloadable freely. The internet also provides rich resources for activities and learning materials that can create enjoyment and fun for the students. The lecturers have taken the most advantage of the resources, such as videos, games, 
and other relevant materials to support their teaching.

In addition to the above solutions or strategies, the strategies proposed by Zhen (2012) to cope with problems in the teaching of literature in EFL context can also be taken into account. They are:

1. Balancing the task of teaching English as a language and promoting literary appreciation.

2. Taking the best advantages of the advancement in technology for teaching and learning.

3. Paying more attention on sequencing the skills to teach.

4. Catering to students' different levels of English proficiency.

5. Using appropriate evaluation and assessment tools.

6. Employing various methods in teaching and learning.

Although the strategies above are too general, as they are not based on the real problems encountered at classroom level, they will still be beneficial for the improvement of English Literature teaching in EFL classes. The problems also open possible topics for future research in this field.

Based on the strategies employed in coping with the problems in teaching English literature, it can be inferred that one of the appropriate English literature instructional models is one that involves a careful selection of literary texts for teaching, which is based on students' levels of proficiency and interest. The model also engages students in group discussion that will allow them to better understand the text, with the teacher getting involved with students individually in order to ensure their compliance with the task and understanding of the assigned reading. An appropriate instructional model of English literature is also one that makes the best use of the existing resources to create enjoyable and fun learning experiences for the students.

\section{CONCLUSIONS}

The research has attempted to shed some light on the teaching and learning of English literature in the undergraduate classes of Indonesian universities, where literature is not treated as a tool, technique, or method of improving English skills. Rather, this research regards English literature as a separate and equally important subject to English language. It has been shown in this research that literature and language are two inseparable parts. Thus, learning English literature also means learning the language and the culture.

In Indonesian context, the teaching of English literature has not garnered much attention from the researchers, while actually this is a promising field of research that opens so many possibilities for research areas or topics. The findings of this research, particularly the problems experienced by English literature lecturers in the classroom, should be carefully and seriously addressed. Students' reading habit, English proficiency, and resources which are the problems identified in this research should be taken into consideration in the practices of teaching English literature at the university level.

It is expected that future researchers will pay more attention to the field of English literature teaching and learning. While this present research has focused on teachers or lecturers, future studies can hopefully make students the subject of their investigation. That way, a more balance view and better understanding of the phenomenon of English literature teaching and learning will be obtained. In addition, as part of the research roadmap, the model resulted in this research will be tested in a subsequent study.

\section{REFERENCES}

Abdullah, I., Zakaria, M. H., Ismail, F., Mansor, W. F. A. W., \& Aziz, M. A. (2007). A new teaching model to teach literature for the TESL pre-training service programme in Universiti Teknologi Malaysia. Research Report.

Aziz , A. \& Syed, N. (2010). An investigation on approaches used to teach literature in the ESL classroom: a case study of Sekolah Menengah Kebangsaan Taman Desa Skudai, Johor Bahru. (Unpublished), pp. 1-7.

Bedi, K. (2011). Language acquisition through literature promotes creativity and thinking skill. The Criterion: An International Journal in English 2(2), pp. 1-6.

Bibby, S. \& Mcllroy, T. (2013). Literature in language teaching SIG. The Language Teacher 37(5), pp. 19-21.

Bjarkadottir, V. (2009). Teaching literature in the tenth grade. Master's Thesis. University of Iceland. Unpublished.

Carpenter, N. (2007). Marginalized Literature in the English Classroom Working with Barbara Ehrenreich's Nickel and Dimed. Honors Theses. Lee Honors College at Scholar Works at WMU.

Carter, R \& Long, M. (1991). Teaching literature. London: Longman.

Chang, H. (2003). Difficulties in studying and teaching literature survey courses in English departments in Taiwan. Dissertation. University of Texas at Austin. Unpublished.

Chang, J. (2009). The role of children's literature in the teaching of English to young learners in Taiwan. Dissertation. University of Waikato. Unpublished.

Chesterman, A. (1983). The teaching of literature to non-native speakers. AFinLA:n Vuosikirja, pp. 135-142. 
Cruz, J. (2010). The role of literature and culture in English language teaching. Relinguistica aplicada 7, 1-16.

Daskalovska, N \& Dimova, V. (2012). Why should literature be used in the language classroom? Procedia - Social and Behavioral Sciences 46, 1182-1186.

Elklic, G., ErGgen, G. E., Kayintu, A \& Karaca, H. (2011). The use of literature in teaching English grammatical structures as well as some linguistic components. Proceedings of the 1st International Conference on Foreign Language Teaching and Applied Linguistics, pp. 490-495.

Floris, F. (2004). The power of literature in EFL classrooms.”K@ta6(1), 1-12.

Ghouti, H. \& Mohammed, K. (2014). Towards an integrative approach to teaching literature in an EFL context. IMPACT: International Journal of Research in Humanities, Arts, and Literature 2(4), 113-126.

Healy, S. (2010). Literature in the EFL classroom: From theory to practice. AHSUSK HS 42, 178191.

Hişmanoğlu, M. (2005). Teaching English through literature. Journal of Language and Linguistic Studies 1(1), 1-14.

Hwang, D. \& Embi M. (2007). Approaches employed by secondary school teachers to teaching the literature component in English. Jurnal Pendidik dan Pendidikan, 22, 1-23.

Kateregga, A. (2014). Towards a holistic approach of teaching and learning literature: Misconceptions about and endangerment of literature in Uganda's schools. Synergies Afrique des Grands Lacs 3, 25-34.

Khalid, A. \& Muhammad, K. (2012). The use of Youtube in teaching English literature. International Journal of Linguistics 4(4), 525551.

Khatib, M., Derakhshan, A., \& Rezaei, S. (2011). "Why and why not literature: A-task based approach to teaching literature. International Journal of English Linguistics 1(1), 213-218.

Khatib, M., Rezaei, S., \& Derakhshan, A. (2011).Literature in EFL/ESL Classroom. English Language Teaching, 4, 201-208.

Li, D. (2011). How to teach and learn English literature in e-education era. International Journal of e-Education, e-Business, $e$ Management and e-Learning 1(3), 241-245.

Llach, P. (2007). Teaching language through literature: The Waste Land in the ESL classroom. Odisea 8, 7-17.

Maley, A. (1989). Down from the pedestal: literature as a resource. In Brumfit, C.J. \& Carter, R.A. (Eds.), Literature and the learner: Methodological approaches (pp. 10-23). London: McMillan.
Malik, R., \& Hamied, F. (2016). Research methods: A guide for first time researchers. Bandung: UPI Press.

McKay, S. (1982). Literature in the ESL classroom. TESOL Quarterly 16(4), 529-536.

Neranjani, S. E. (2011). Enhancing literary competence through activity based literature learning. Master's Thesis, University of Colombo. Unpublished.

Padurean, A. (2015). Approaches to teaching literature in EFL classrooms. Journal of Romanian Literary Studies 6, 195-200.

Rashid, R. A., Vethamani, M. E., Rahman, S. B. A. (2010). Approaches employed by teachers in teaching literature to less proficient students in Form 1 and Form 2. English Language Teaching 3(4), 87-99.

Riverol, J. (1991). Literature in the teaching of English as a foreign language. Revista Alicantina de Estudios Ingleses 4, 65-69.

Saka, Ö. (2014). Short stories in English language teaching. International Online Journal of Education and Teaching (IOJET), 1(4), 278288.

Sell, J. (2005). Why teach literature in the foreign language classroom? Encuentro 15, 86-93.

Sidhu, G. K., Fook, C. Y., \& Kaur, S. (2010). Instructional practices in teaching Literature: Observations of ESL classrooms in Malaysia. English Language Teaching 3(2), 54-63.

Tasneen, W. (2010). Literary texts in the language classroom: A study of teachers and students' views at international schools in Bangkok. The Asian EFL Journal 12(4), 1-17.

Than, A. (2002). What Literature to Teach? Galaxy 3(3), 40-44.

Tseng, Fan-ping. (2010). Introducing literature to an EFL classroom: Teacher's presentations and students' perceptions. Journal of Language Teaching and Research 1(1), 53-65.

Turker, F. (1991). Using "literature" in language teaching. Hacettepe Universitesi Egitim Fakultesi 6, 299-305.

Van, M. (2009). The relevance of literary analysis to teaching literature in the EF classroom. English Teaching Forum 3, 2-9.

Vasuthavan, S. S. E. \& Kunaratnam, S. (2009). Teaching poetry to reluctant learners in a form four ESL classroom. Proceedings of the 2nd International Conference of Teaching and Learning, pp. 1-8.

Vural, H. (2013). Use of literature to enhance motivation in ELT classes. Mevlana International Journal of Education 3(4), 1523.

Yavuz, A. (2010). Enhancing creativity in the communicative language classroom through poetry as a literary genre." Dil Dergisi (Language Journal) 149, 64-79. 
Yeasmin, N., Azad, Md. A. K., \& Ferdoush, J. (2011). Teaching language through literature: Designing appropriate classroom activities. ASA University Review 5(2), 283-297.

Zhen, C. (2012). Characteristics and strategies of literature teaching in the EFL context in China.
International Journal of Electronics and Communication Engineering 5(3), 35-43. Zyngier, S. (1994). Literature in the EFL Classroom: Making a comeback. The Poetics and Linguistics Association 6, 1-17. 